-

\title{
Mobbing in a Non-Profit Organisation
}

\author{
Andrej Kovacic ${ }^{1}$, Nevenka Podgornik ${ }^{2}$, Zorica Pristov ${ }^{3}$, Andrej Raspor ${ }^{4}$ \\ ${ }^{1}$ University of Udine (Gorizia branch), Italy \\ andrej.kovacic@ceos.si \\ ${ }^{2}$ School of Advanced Social Studies Nova Gorica, Slovenia \\ nevenka.podgornik@fuds.si \\ ${ }^{3}$ Independent researcher, Slovenia \\ zoricapristov@gmail.com \\ ${ }^{4}$ DOBA Faculty of Applied Business and Social Studies, Maribor and \\ School of Advanced Social Studies, Nova Gorica, Slovenia \\ andrej.raspor@ceatm.org
}

\begin{abstract}
Purpose: The aim of this paper is to analyse mobbing in a large, non-profit, state-owned organization in order to find out to what extent mobbing is present and in what way it takes place. In addition, the purpose of the research is to analyse whether the extent of mobbing is connected to employee's age, gender and position.

Methodology: In this quantitative research, a total of 355 opinions were collected using a random selection procedure within the selected large size, state-owned organization (between 1000 and 2000 employees). The results of the employees' experiences of mobbing were statistically analysed and tested.

Results: Similar to other researches, a third of all respondents stated they have been affected by mobbing in the last three years. Additionally, we found out that younger employees are not affected more than older. Interestingly, there are also no gender differences as both genders seem to be affected similarly. Also, a management position does not mean a person is less exposed to mobbing. Finally, we confirmed that the most frequent type of mobbing is vertical mobbing (carried out by an employer / manager on employees or vice versa).

Originality / value: The study fills a current gap in the research and understanding of mobbing in non-profit organizations in Slovenia as it presents the magnitude of mobbing experiences as well as the relations between the attackers and victims. The study also provides a good starting point for further research on this sensitive subject.

Research limitations / conclusions: Since the research was limited to one non-profit organization, it makes sense to explore the phenomenon in different individual profit companies as well as non-profit organisations in order to create plans for preventing and limiting mobbing.
\end{abstract}

Keywords: mobbing; gender; organization; culture; conflicts; bullying

\section{Introduction}

Because of the proven harmful effects on the health, behaviour and productivity of employees and, consequently, the functioning of companies, mobbing has become an important area of academic research. Mobbing is namely one of the most unpleasant work-related experiences an employee can be exposed to. Regardless of the subjective na- ture of experience that causes a person to classify a conflict as mobbing, these conflicts have to be resolved as soon as possible. If not resolved, mobbing conflicts can escalate. All the above mentioned is supported also by Horvat and Pagon (2012) who argue that low willingness to report the perpetrator, lenient disciplinary sanctions and the absence of proper organizational rules create favourable conditions for workplace mobbing. 
The term 'mobbing' is more frequently used in Germany, Scandinavia and Italy, while 'bullying' is the more common term in English speaking countries. In this article, both forms are used as used in the original works of different authors. While in the Northern (primarily in Sweden) and Western European countries mobbing has been researched in various aspects for three decades, this phenomenon is still relatively little known and studied in the societies of some post-communist countries (Vveinhardt \& Sroka, 2017). Particularly little knowledge is available about the prevalence of mobbing and forms of its occurrence in non-profit organizations, which are not as complex organizational structures (from the perspective of human resources and the interests of enterprise stakeholder groups in a safe working environment) as profitable companies.

In a non-profit organization, one would not expect to encounter so much exploitation of employees as known in profitable sector. According to this logic, psychological and physical pressures on employees should also, in a way, be smaller. The presence of mobbing in Slovenian companies has already been studied by Brečko (2003), Mumel, Jan, Treven, and Malc (2015)which represents a serious, widespread problem with numerous consequences for victims, organizations, and society. We also recognize the connection this phenomenon has with the emergence of post-traumatic stress disorder (PTSD, confirming its presence as well as its influence on the stress level of workers. Based on their works, we set the following research question: To what extent is mobbing present in non-profit organizations?

\section{Theoretical Background}

The intention with mobbing is clear and cannot be misinterpreted. Mobbing always starts with a conflict. If the conflict is not solved, it can evolve into mobbing. Mobbing assaults the dignity, integrity, and credibility of the worker. This type of emotional abuse can be devastating for the individual. Tkalec (2001)katerega je raziskal ter poimenoval svedski psiholog dela Heinz Leymann. S formulacijo "sikaniranje na delovnem mestul" je opisoval situacijo, v kateri je posameznik v podjetju sistematicno, pogosto ter skozi daljse casovno obdobje izpostavljen napadom sodelavcev in/ali nadrejenih (Leymann, 1995: 18 argues that any bullying starts with a conflict, however, it is not necessary that every conflict ends with bullying. If a conflict is not resolved and the bullying increases in magnitude, the first conflict becomes meaningless. Whenever two people establish a relationship, conflicts can arise. But despite the negative connotation of the word conflict we should not understand it only as something negative. Lipičnik (1998) argues that there is also a positive side of conflicts since they point out to the problems which demand solutions. In real life, problems between subcultures in an organization are sometimes avoided for the sake of "peace." Berlogar (2006) distinguishes between different types of conflicts in organizations: between employees, between management, between employees and other people, between owners and between different organizations. In contrast to conflicts, mobbing is always negative. Leymann (1990), the pioneer researcher of mobbing, thus defined the term as "psychological terror" or "mobbing in work life." According to Leymann (1990), mobbing means hostile and unethical communication which is directed in a systematic way by one person or a number of people mainly towards one individual. Leymann (2012) adds that mobbing can take place occasionally or every day for a long period of time. The actions are systematically directed towards one individual who is, because of them, pushed into a situation from which he or she cannot escape. The victim does not believe he or she can be protected. All these hostile acts aimed at the individual cause psychological and physiological problems (Brečko, 2013). There are other terms that describe mobbing (Table I). However, these terms cannot fully explain the basic meaning of the word mobbing.

Mobbing is commonly used to describe all situations where a worker, a supervisor, or a manager, is systematically, repeatedly mistreated and victimized by fellow workers, subordinates or superiors (Shelton, 2011). The International Labour Office (ILO), in 1998, categorized mobbing in the same category as homicide, rape, or robbery (Davenport, Schwartz, \& Pursell Elliott, 2005).

Mlinarič (2007) grouped Leymann's 45 forms of mobbing into 5 groups: attacks on communication, threats about personal connections, attacks on personal reputation, obstructing work and endangering health. According to Divincova \& Sivakova (2014), the most frequent factors that could lead to mobbing are: superiority of the mobber, selfishness, personal issues often stemming from problems at home, complexes, jealousness, mutual dislike, achievement of career growth and psychological terror at the expense of another. Brousse et al. (2008) tested Leymann's Inventory of Psychological Terror criteria for bullying as an indicator and showed that $81 \%$ of patients showed high levels of perceived stress at work. Sutton (2010) additionally explains that different attacks, such as personal insults and status attacks cause degradation of the victim's social position and pride in the form of status degradation. These personal insults are usually disguised by jokes or ignorance. When the abuse begins, other people gradually exclude the victim from their world. Goleman (2010) points out that because of social rejection people can suffer from a special form of grief caused by difficult and threatening relationships. Because victims do not react but suppress the anger instead, they silently communicate to the mobber that he can carry on with mobbing. Moreover, if others are passive when the victim is attacked for the first time, the mobber understands the lack of reaction as ap- 
Table 1: Terms Describing Mobbing

Source: Shelton, 2011.

\begin{tabular}{|c|c|c|}
\hline Reference & Terms & Definition \\
\hline Brodsky (1976) & Harassment & $\begin{array}{l}\text { Repeated and persistent attempts by a person to torment, wear down, frus- } \\
\text { trate, or get a reaction from another person; it is a treatment which persistent- } \\
\text { ly provokes, pressures, frightens, intimidates or otherwise causes discomfort } \\
\text { in another person. }\end{array}$ \\
\hline Thylefors (1987) & Scapegoating & $\begin{array}{l}\text { One or more persons who, during a period of time, are exposed to repeated, } \\
\text { negative actions from one or more other individuals. }\end{array}$ \\
\hline $\begin{array}{l}\text { Matthiessen, } \\
\text { Raknes, \& Rrok- } \\
\text { kum (1989) }\end{array}$ & Mobbing & $\begin{array}{l}\text { One or more person's repeated and enduring negative reactions and conducts } \\
\text { targeted at one or more person of their work group. }\end{array}$ \\
\hline Leymann (1990) & $\begin{array}{l}\text { Mobbing/Psychologi- } \\
\text { cal terror }\end{array}$ & $\begin{array}{l}\text { Hostile and unethical communication that is directed in a systematic way by } \\
\text { one or more persons, mainly towards one targeted individual. }\end{array}$ \\
\hline Kile (1990a) & $\begin{array}{l}\text { Health endangering } \\
\text { leadership }\end{array}$ & $\begin{array}{l}\text { Continuous humiliating and harassing acts of long duration conducted by a } \\
\text { superior and expressed overtly or covertly. }\end{array}$ \\
\hline Wilson (1991) & Workplace & $\begin{array}{l}\text { The actual disintegration of an employee's fundamental self, resulting from } \\
\text { an employer's or supervisor's perceived or real continual and deliberate ma- } \\
\text { licious treatment. }\end{array}$ \\
\hline Ashforth (1994) & Petty tyranny & $\begin{array}{l}\text { A leader who lords his power over others through arbitrariness and self-ag- } \\
\text { grandizement, the belittling of subordinates, showing lack of consideration, } \\
\text { using a forcing style of conflict resolution, discoursing initiative and the use } \\
\text { of non-contingent punishment. }\end{array}$ \\
\hline Vartia (1993) & Harassment & $\begin{array}{l}\text { Situations where a person is exposed repeatedly and over time to negative } \\
\text { action on the part of one or more persons }\end{array}$ \\
\hline $\begin{array}{l}\text { Bjorkqvist, Oster- } \\
\text { man (1994) }\end{array}$ & Harassment & $\begin{array}{l}\text { Repeated activities with the aim of bringing mental (but sometimes also } \\
\text { physical) pain, and directed towards one or more individual who, for one } \\
\text { reason or another, are not able to defend themselves }\end{array}$ \\
\hline Adams (1992a) & Bullying & $\begin{array}{l}\text { Persistent criticism and personal abuse in public or private, which humiliates } \\
\text { and demeans a person }\end{array}$ \\
\hline
\end{tabular}

proval (Staub \& Pearlman, 2009). As Staub and Pearlman (2009) claim, nothing can stop the mobber at that point.

Mobbing has many negative consequences. First of all, it influences organizational success as it lowers social capital. An organization, therefore, must persist in creating favourable working conditions for a long-term success and survival. The main components of social capital are: trust, reciprocity, and social networking. All three components can be affected when mobbing is present (Nahapiet \& Ghoshal, 1998). Mobbing also indirectly lowers productivity (Divincova \& Sivakova, 2014; Josipovic-Jelic, Stoini, \& Celic-Bunikic, 2005). Finally, mobbing is also connected to organizational commitment in the workplace (Yuksel \& Tunçsipe, 2011). Specifically, Shallcross, Sheehan, \& Ramsay (2008) have discovered the toxic nature of public sector because of mobbing behaviour and workplace expulsion. Arnejčič (2016) in this respect provides additional literature review and comments.

Mobbing is also influenced by organizational culture and vice versa. If mobbing is unacceptable and often discussed, the possibilities to commit mobbing are very limited (Biloslavo, 2008). On the other hand, when being tolerated, mobbing can dramatically influence the organizational culture in different aspects. Since culture is a dynamic category that evolves through time, it is very important that organizations strive to control the organizational culture, because opinions, values, norms, principles and habits, beliefs and behaviour constantly change (Živko, Zver, \& Bobek, 2005).

The negative effects of mobbing directly influence organizational climate which is an indicator of how employees comprehend organization (Meško Štok, 2009). Berlogar (2006) thus describes the satisfaction of employees working in a safe environment and a belief that high self-respect is vital for company success. Self-respect and self-valuation are connected to the opinion of the "important others." Makarovič and Rek (2014) stress the need for a positive self-valuation as a basic human need. Even more, Lipičnik and Možina (1993) see organizational climate as a pre-condition for achieving quality standards and excellence. On the other hand, the authors argue that bad interpersonal relations in companies can have an even 
greater negative effect on work motivation than physical working conditions. According to the results of Okçu and Çetin (2017), the teachers' job satisfaction level decrease in line with an increase in their mobbing experiences related to their profession and social relationships, and thus, their burnout levels also increase (Okçu \& Çetin, 2017).

NHS (Carter et al., 2013) performed a workplace bullying survey in the UK NHS research and discovered that an overall $20 \%$ of staff reported having been bullied by other staff to some degree and $43 \%$ reported having witnessed bullying in the last 6 months. In addition, male staff and staff with disabilities reported higher levels of bullying. Employees who were victims claimed to have less work commitment and experienced feelings of stress, depression, anxiety and the wish to change the work environment. Similarly Workplace Bullying Survey by WBI (WBI, 2014) showed that $27 \%$ of employees have been bullied at work. Almost three quarters of Americans are aware of the problems of bullying in their work environment. $72 \%$ of employees deny that bullying is taking place in their companies. Almost all (93\%) of employees would like to have changes in the legislation to prevent mobbing in their work environment. In a research in Slovenia, Brečko (2003) points out that the most frequent mobbing victims are: employees who have pointed to the irregularities in the company, young employees, employees with high income, employees who want changes in the work environment, employees who want more independence, and minorities (especially sex and race minorities). According to Babnik, Štemberger Kolnik, and Majcan (2012), occupations that are the most frequently exposed to mobbing are the ones in the health sector.

In Slovenia there are two laws that prohibit mobbing in the work place: Employment Relationship Act (Zakon o delovnih razmerjih, 2013) and Civil Servants Act (Zakon o javnih uslužbencih, 2007). In addition, the Decree on measures for protecting the worker's dignity at work in state administration from 2009 defines different forms of mobbing as well as obligations of the managers and action steps. The rights to personal dignity are written also in the Articles 34 and 35 of the Slovenian Constitution and in the Article 6 of the Employment Relationship Act which prohibits bullying at the workplace or in connection to work (Zakon o delovnih razmerjih, 2013). Bullying is described as any "repetitive or systematic, reprehensible or clearly negative and insulting action or behaviour aimed at individual workers in the workplace or in connection with work" (Zakon o delovnih razmerjih, 2013). Additionally, Civil Servants Act puts employers under obligation to protect civil servants from being offended, attacked by threats and other similar actions. Also any physical, verbal or non-verbal abuse or behaviour of a public servant in any circumstance that creates a threatening, hostile, humiliating or offending work environment is restricted (Zakon o javnih uslužbencih, 2007). At the EU level, dignity rights are written in the European Social Charter ratified by Slovenian government. Besides Articles 3 and 11, Article 26 deals directly with mobbing. It demands protection in the work environment as well as education, informing and protection against repeated abuse.

Despite the substantial legislation, there are only few cases of mobbing in legal practice. In legal information system we can track only cases on higher and social court where there were 23 cases of mobbing between 2004 and

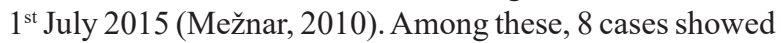
that the misconduct was not mobbing and only in 12 cases the ruling involved mobbing. Only in 9 cases financial compensation was awarded to the victims of mobbing.

\section{Methods}

In this quantitative research, a total of 355 opinions were collected using a random selection procedure within the selected large size state-owned organization (between 1000 and 2000 employees). The results were gathered by using an online questionnaire designed in order to collect employees' experiences of mobbing. The participation rate was high (more than $80 \%$ ). The data was collected within one month at the beginning of 2015 and was statistically analysed and tested using SPSS.

\subsection{Research Instrument}

To measure the quantity of bullying, a part of $W B I$ - Workplace Bullying Institute Questionnaire (Namie, Christensen, \& Phillips, 2014) was used. We adjusted the questions for Slovenian population as well as tested and revised the questionnaire before the final version.

To measure the quantity of bullying, a part of $W B I$ - Workplace Bullying Institute Questionnaire (Namie, Christensen, \& Phillips, 2014) was used. We adjusted the questions for Slovenian population as well as tested and revised the questionnaire before the final version. To test the questionnaire we conducted preliminary research small scale analysis (10\% of the final sample) and revised the disparity of answers as well as the general understanding of the questions.

The first part of the questionnaire collected information on gender, age, work experience and position. The second part of the questionnaire included 12 statements on mobbing measured on 5-point Likert scale. The third part consisted of four questions regarding the quantity or presence of perceived mobbing and the attacker position. Through the random sampling procedure we managed to collect opinions from 355 respondents (321 female and 34 male). Sample gender ratio reflected the organization gender ratio 9:1 in favour of females. Sampled employees were almost equally divided into two age groups: 21 to 40 years and above 41 years. There were $16 \%$ of managers in the sample. 


\subsection{Hypotheses}

Based on the review of the theories we set the following research question: To what extent is mobbing present in non-profit organizations?

We set the following hypotheses:

H1: Younger employees (bellow 40) experience mobbing more often than 41- to 60-year-olds.

With this hypothesis we want to determine whether the subjective perception of mobbing in younger employees is different from the perception of older (Turhan, 2014; Aricioğlu, Tanoglu, \& Kocabaş, 2007). These changes in perception, as well as some behavioural patterns, are in some aspects the consequences of permissive education. In addition, it is also necessary to consider the fact that the types of management changed in the last 25 years. If there was a more authoritative type of management in the previous system, nowadays we mostly encounter a more participatory management type.

\section{H2: Female employees experience mobbing more often.}

Following other previously conducted research, women are more liable to bullying and thus more vulnerable than men (Turhan, 2014; Aricioğlu, Tanoglu, \& Kocabaş, 2007). When the former are younger, this is usually manifested through sexual harassment. Later in the stage of motherhood they are subjected to absenteeism due to (ill) children in need of care. It is usually expected, especially by managers, that women are not absent (Qureshi, Rasli, \& Zaman, 2014).

\section{H3: Non-managers experience mobbing more often.}

It is usually more difficult for employees to resist mobbing from the managers (Turhan, 2014; Aricioğlu, Tanoglu, \& Kocabaş, 2007). It is easier for the latter to resist mobbing from those employed on lower positions - but at the same time managers are not immune to being exposed to mobbing. In addition, it should be noted that mobbing is also present among the same rank employees. With this hypothesis we would like to determine which group perceived and experienced mobbing the most.

\section{H4: The most frequent attacker was the manager (one per- son).}

With this hypothesis we wanted to find out whether it is likely for mobbing to be on the individual basis or it is more common that more than one person attack an individual person (collective mobbing). The possibility that mobbing is an integral part of the organizational culture and that mobbing takes place among the whole team/personnel
(Turhan, 2014; Aricioğlu, Tanoglu, \& Kocabaş, 2007), was also taken into account.

\section{Results}

In the last three years, $31.8 \%$ of employees experienced mobbing and more than a half $(53.1 \%)$ have witnessed or heard of it within the organization. We tested hypothesis H1 that younger (bellow 40) employees experience mobbing more often than 40 - to 60 -year-olds. A Chi-Square goodness of fit was calculated comparing the frequencies of occurrence of mobbing in both groups. It was hypothesized that younger and older group would occur an equal number of times. Significant deviation was not found $\chi(2)$ $=1.418, \mathrm{p}>0.05$. Younger $(21-40$-year old employees $)$ experience mobbing more often $(34.8 \%)$ than the 41 -to 60 -year-olds (30.3\%). However, the difference is not substantial. Thus, we can conclude that there are no significant differences between the age groups and we can reject $\mathrm{H} 1$.

Similarly, we tested $\mathrm{H} 2$ and discovered that there are also no significant differences between genders. Significant deviation was not found $\chi(1)=0.517, p>0.05$. Male employees $(35.3 \%)$ are even somewhat more exposed to mobbing than female $(31.2 \%)$ and we can reject $\mathrm{H} 2$.

We also tested $\mathrm{H} 3$ to find out if non-managers experience mobbing more often than managers. The results show that almost the same percentage of managers experienced mobbing $(31.2 \%)$ as non-managers $(32.1 \%)$. Significant deviation was also not found $\chi(1)=0.024, p>0.05$.

Finally, we tested $\mathrm{H} 4$ to find out if the most frequent attacker is a manager (one person), co-worker or several people together. Unlike the other hypothesis, we can accept $\mathrm{H} 4$ as significant deviation was also found $\chi(3)=$ $0.03, p<0.05$. In most cases ( $44 \%)$ the attacker was indeed a single person and a manager. This was followed by a co-worker (32\%), many people together (in $15 \%$ of cases) and worker mobbing the manager $(9 \%)$.

\section{Discussion}

The results of our study have shown similarities to the results from other studies. For example, Picakciefe, Acar, Colak, and Kilic (2015) showed that $31.1 \%$ of health workers have experienced mobbing in the last year. Similarly, the results of Gök (2011) showed that among their respondents $32 \%$ were victims of mobbing during the entire working life and $16 \%$ of participants within the last year. Almost half of the victims claim to have had health problems as a result of having suffered mobbing in their workplace (da Silva João \& Portelada Saldanha, 2016). In Swiss nursing homes, $4.6 \%$ of the surveyed care workers reported mobbing experiences in the last 6 months (Tong, Schwendimann, \& Zúñiga, 2017).

In Uruguay, in both hospitals and schools mobbing is 
Table 2: The frequency of mobbing (the percentage of employees)

\begin{tabular}{|c|c|c|c|c|c|c|}
\hline & $\begin{array}{l}1 \text { time in the } \\
\text { last three } \\
\text { years }\end{array}$ & $\begin{array}{l}1 \text { time in the } \\
\text { last year }\end{array}$ & $\begin{array}{c}\text { Every } \\
\text { month in the } \\
\text { last year }\end{array}$ & $\begin{array}{c}\text { Every week } \\
\text { in the last } \\
\text { year }\end{array}$ & $\begin{array}{l}\text { Every day in } \\
\text { the last year }\end{array}$ & $\begin{array}{l}\text { Total (an- } \\
\text { swers) }\end{array}$ \\
\hline Attacker is a manager & $36.9 \%$ & $33.6 \%$ & $18.8 \%$ & $8.7 \%$ & $2.0 \%$ & 149 \\
\hline Attacker is a co-worker & $41.3 \%$ & $24.8 \%$ & $18.3 \%$ & $11.9 \%$ & $3.7 \%$ & 109 \\
\hline Many attackers & $45.1 \%$ & $25.5 \%$ & $13.7 \%$ & $11.8 \%$ & $3.9 \%$ & 51 \\
\hline $\begin{array}{l}\text { Attacker is a worker } \\
\text { attacking management }\end{array}$ & $56.3 \%$ & $15.6 \%$ & $21.9 \%$ & $3.1 \%$ & $3.1 \%$ & 32 \\
\hline
\end{tabular}

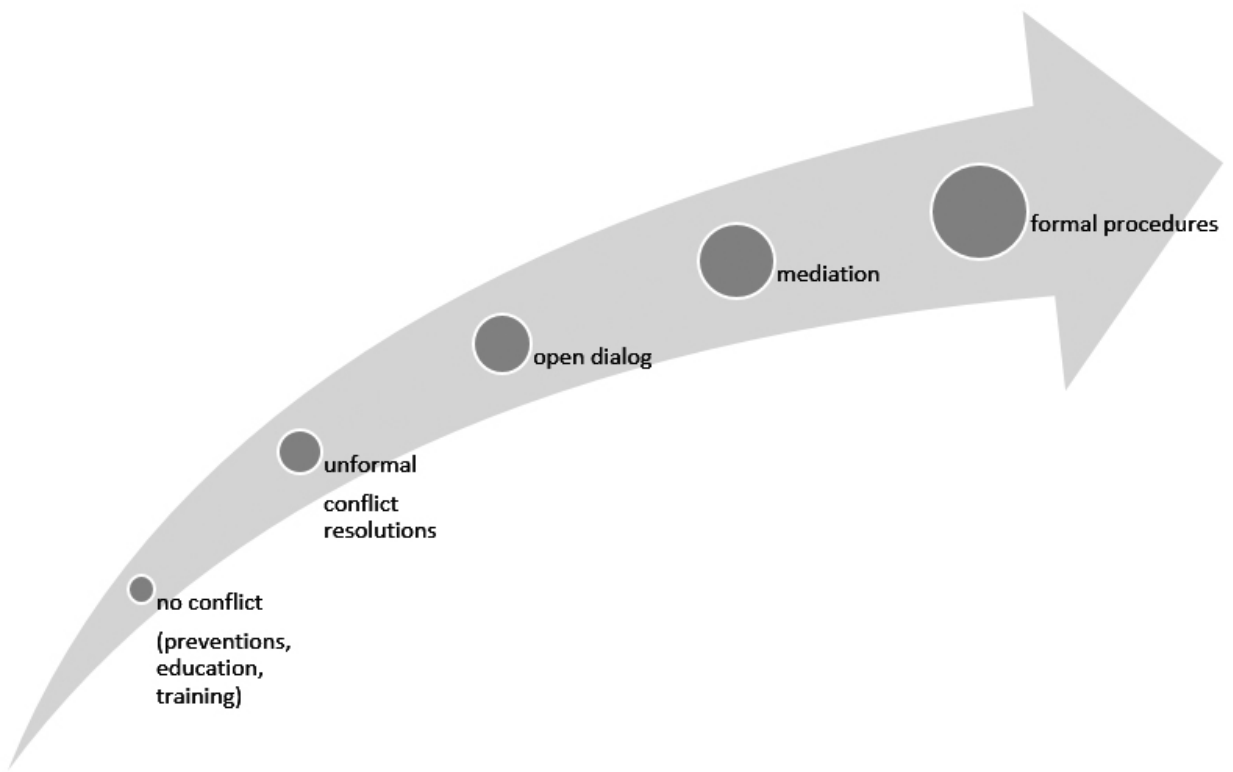

Figure 1. Handling Conflict Situations

Source: adapted from Review of Mediation Services (NHS, 2009)

more frequent among older employees, among employees who are better educated and who have been employed for a longer time. Men and women did not differ in reporting mobbing, but men reported more perceived loss of status than women. However, among women, being the victim of mobbing was strongly related to experiencing a loss of status than among men (Buunk, Dijkstra, Franco, \& Zurriaga, 2017).

On a path to prevention, Brečko (2007) points out that the most important issue when dealing with mobbing is early detection. Therefore, activities in organisations must focus on improvement of both management and organizational culture. Work should be organized as teamwork. Conditions that minimize the possibility for mobbing include the improvement of organizational climate that involves open communication, clear information transfer, and possibilities for education and improvement. In addition, like in some examples of foreign companies, previously agreed procedures for reaction on mobbing with detailed information on sanctions could be introduced. Finally, systematic education and information about formal procedures in connection to mobbing could be provided for all employees. Examples where formal procedures and internal regulations have been accepted are numerous. For example, the Cardiff University created a document Dignity At Work And Study Policy (2015) in which detailed procedures are described in order to minimize the possibilities of occurrence of mobbing. Similarly, NHS (2009) created a document A Review of Mediation Services on the Basis of In-House Research of Mobbing where they discovered that procedures in conflicts are not followed through to avoid future conflicts. Thus, NHS suggests a diagram for 
handling conflict situations, which can be seen in Figure 1.

The NHS diagram clearly shows the need to formalize procedures in all steps of conflict solving and mobbing prevention. In the organization policies it has to be stated that mobbing will not be tolerated and is against the policies of an organization. In addition, organisations have to provide personnel that victims can ask for help and advice. Providing the personnel that victims trust and know that they are capable in helping them may be the most difficult issue when dealing with mobbing. Namely, the personnel, in addition to being trustworthy, has to be competent to act in mobbing situations as well as have sufficient knowledge and skills to be able to help victims with advice and support. Beside the personnel, outside experts could provide additional support as well as training. When formal procedures are in place a wider group of employees should be included in the solving of the problem in order to prevent similar situations in the future. Nothing stated above can be achieved without sufficient support from the top management, which have to stand strong on the issues written in documents and legislation and bring procedures into effect.

\section{Conclusion}

According to the research question, we discovered that mobbing is indeed present on a large scale in non-profit organizations, which is consistent with other research conducted in this field (Turhan, 2014; Aricioğlu, Tanoglu, \& Kocabaş, 2007; Kaya et al., 2015). Interestingly, in our study, women do not experience mobbing more often than men. An employee is being influenced substantially in the work environment by internal and external factors and mobbing seems to play an important role. Achieving quality and quantity standards thus not only consists of improving individual working skills but also improving external influence factors. Therefore, the ability to prevent and solve conflicts is essential for an organization not only to prevent mobbing but also to increase social capital and thus be more productive and achieve high quality. Manotas (2015) analysed mobbing in an educational institution arguing that institutions can build healthy environments for their employees. However, finding a solution to this serious issue is difficult for any organization, especially for a non-profit institution, as it seems that formal procedures fail as well. Regulation is present, but legal cases are few, and since almost a third of employees experience mobbing, obviously something is not working (Babnik et al., 2012). So in addition to Karakas and Okanli (2015), who showed that assertiveness training is an effective method for decreasing mobbing, it is important to consider the results of this study as a strong incentive for future research and further action on organizational and national level. Despite the fact that this research has limitations, it fills a current gap in research and in the understanding of mobbing in non-profit organizations in Slovenia. As the research was limited to one non-profit organization, a comprehensive study should be done in the future, in order to derive the appropriate measures for restricting mobbing.

Managers in non-profit organizations should pay more attention to identifying types and forms of mobbing as well as use more participatory types of management. Associates exposed to mobbing should receive adequate protection and violators should be reported. This way, understanding mobbing in non-profit organizations could contribute to developing a friendlier work environment while employees would be more devoted to their work. As a consequence, quality and quantity of the work performed would increase.

\section{Acknowledgements}

Andrej Kovacic was supported by Slovenian Research Agency by receiving a postdoctoral research grant (63169/2015-13, 1.10.2015).

\section{References}

Arıcıoğlu, M. A., Tanoglu, S. C., \& Kocabaş, M. (2007). Research on mobbing in organizations: A case study on academicians. Proceedings of the 37th International Conference on Computers and Industrial Engineering, 558-568.

Arnejčič, B. (2016). Mobbing in Company: Levels and Typology. Organizacija, 49(4), 240-250, http://dx.doi. org/10.1515/orga-2016-0021

Babnik, K., Štemberger Kolnik, T., \& Majcan, N. (2012). Predstavitev rezultatov dela raziskave "Nasilje nad medicinskimi sestrami na delovnem mestu": oblike, pogostost in povzročitelji psihičnega nasilja [Presentation of the results of the study "Violence against nurses in the workplace": forms, frequency and perpetrators of psychological violence]. Obzornik zdravstvene nege, (46), 147-156.

Berlogar, J. (2006). Osebni in družbeni vidiki komuniciranja v javni upravi [Personal and social aspects of communication in public administration]. University of Ljubljana, Faculty of Administration.

Biloslavo, R. (2008). Strateški menedžment in menedžment spreminjanja [Strategic management and management of change]. University of Primorska, Faculty of Management.

Brečko, D. (2003). Mobing - psihično in čustveno nasilje na delovnem mestu [Mobbing - psychological and emotional violence at workplace]. HRM. GV - izobraževanje.

Brečko, D. (2007). Mobbing - kako ga pravočasno prepoznati in ukrepati [Mobbing - How to recognize it and take actions in time]. VI. dnevi delovnega prava 
in socialne varnosti, May 21-22 2007 (pp. 415-428). Ljubljana: Inštitut za delo pri Pravni fakulteti.

Brečko, D. (2013). Recite mobingu ne: preprečevanje psihičnega in čustvenega nasilja [Say no to mobbing: Prevention of psychological and emotional violence]. Ljubljana: Planet GV.

Brousse, G., Fontana, L., Ouchchane, L., Boisson, C., Gerbaud, L., Bourguet, D., Perrier, A., Schmitt, A., Llorca, P. M., and Chamoux, A. (2008). Psychopathological features of a patient population of targets of workplace bullying. Occupational Medicine - Oxford, 58(2), 122128, https://doi.org/10.1093/occmed/kqm148

Buunk, A. P., Dijkstra, P., Franco, S., \& Zurriaga, R. (2017). Mobbing in Schools and Hospitals in Uruguay: Prevalence and Relation to Loss of Status. Journal of Interpersonal Violence, 32(5), 623-634, http://dx.doi. org $/ 10.1177 / 0886260515625903$

Carter, M., Crampton, P., Morrow, G., Burford, B., Illing, J., Thompson, N., \& Gray, C. (2013). Workplace bullying in the UK NHS: A questionnaire and interview study on prevalence, impact and barriers to reporting. BMJ Open, 3(6), http://dx.doi.org/10.1136/bmjopen-2013-002628

da Silva João, A. L., \& Portelada Saldanha, A. F. (2016). Mobbing and Its Impact on Interpersonal Relationships at the Workplace. Journal of Interpersonal Violence, https://doi.org/10.1177/0886260516662850

Davenport, N., Schwartz, R. D., \& Pursell Elliott, G. (2005). Mobbing: Emotional abuse in the American workplace. Arnes [IA]: Civil Society.

Dignity At Work And Study Policy. (2015). Retrieved from http://www.cardiff.ac.uk/govrn/cocom/equalityanddiversity/dignityatwork/

Divincova, A, B., \& Sivakova. (2014). Mobbing at Workplace and its Impact on Employee Performance. Retrieved from https://frcatel.fri.uniza.sk/hrme/ files/2014/2014_2_02.pdf

Gök, S. (2011). Prevalence and types of mobbing behavior: A research on banking employees. International Journal of Human Sciences, 8(1), 318-334.

Goleman, D. (2010). Socialna inteligenca: nova veda o odnosih med ljudmi [Social intelligence: The new science of human relations]. Ljubljana: Mladinska knjiga.

Josipovic-Jelic, Z., Stoini, E., \& Celic-Bunikic, S. (2005). The effect of mobbing on medical staff performance. Acta clinica Croatica, 44(4), 347-352.

Karakas, S. A., \& Okanli, A. (2015). The Effect of Assertiveness Training on the Mobbing That Nurses Experience. Workplace Health \& Safety, 63(10), 446-451, https://doi.org/10.1177/2165079915591708

Kaya, O., Çobanoğlu, N., Kaya, K., Özdem, E., Angay, A., Akgün, F., Akgün, F., Eser, G., and Gökalp, S. (2015). The Evaluation of Mobbing Cases Which Teachers Experience In High Schools (Sample of Mersin Province). Scholars Journal of Economics, Business and
Management, 2(9), 944-948.

Krsnik Horvat, B., \& Pagon, M. (2012). Attitudes toward workplace mobbing in Slovenian research organisations. Organizacija, 4(45), 159-173, https://doi. org/10.2478/v10051-012-0018-0

Leymann, H. (1990). Mobbing and psychological terror at workplaces. Violence and Victims, 5(2), 119-126. Retrieved from http://www.mobbingportal.com/LeymannV\%26V1990(3).pdf

Leymann, H. (2012). Somatic and psychological symptoms after the experience of life threatening events. A profile analysis. Victimology, 10(4), 512-538.

Lipičnik, B. (1998). Ravnanje z ljudmi pri delu. Ljubljana: Gospodarski vestnik.

Lipičnik, B., \& Možina, S. (1993). Psihologija v podjetjih [Psychology in corporations]. Ljubljana: Državna založba Slovenije.

Makarovič, M., \& Rek, M. (2014). Power and Influence-Based Political Participation in European Democracies. Sociológia, 46(6), 686-705.

Manotas, E. (2015). Mobbing in Organisation: Analysis of Pericular Cases in Higher Educational Institution. Procedia - Social and Behavioural Sciences, 191, 16071612, http://dx.doi.org/10.1016/j.sbspro.2015.04.470

Meško Štok, Z. (2009). Management znanja v sodobnih organizacijah [Management of knowledge in modern organizations]. Koper: Fakulteta za management.

Mežnar, Š. (2010). Odškodnina v primeru kršitve prepovedi diskriminacije in mobbinga [Compensation in case of violation of the prohibition of discrimination and mobbing]. Delavci in Delodajalci, 10(2-3), 439-458. Retrieved from http://www.delavciindelodajalci.com/ S30000/Arhiv

Mlinarič, P. (2007). 45 mobing dejanj [45 acts of mobbing]. Retrieved from http://www.mobing.si/index.html

Mumel, D., Jan, S., Treven, S., \& Malc, D. (2015). Mobbing in Slovenia: prevalence, mobbing victim characteristics, and the connection with post-traumatic stress disorder. Naše Gospodarstvo, (61), 3-12, https://doi.org/10.1515/ngoe-2015-0001

Nahapiet, J., \& Ghoshal, S. (1998). Social Capital, Intellectual Capital, and the Organizational Advantage. The Academy of Management Review, 23(2), 242-266, https://doi.org/ 10.2307/259373

Namie, G., Christensen, D., \& Phillips, D. (2014). WBI U.S. workplace bullying survey, Workplace bullying institute. Retrieved May 10, 2015, from http://www. workplacebullying.org/wbiresearch/wbi-2014-us-survey

NHS (2009). Retrieved from http://www.staffgovernance. scot.nhs.uk/improving-employee-experience/dignityat-work-project/review-of-mediation-services/

Okçu, V., \& Çetin, H. (2017). Investigating the Relationship among the Level of Mobbing Experience, Job Satisfaction and Burnout Levels of Primary and Seconda- 
ry School Teachers. Universal Journal of Educational Research, 5(1), 148-161, https://doi.org/10.13189/ ujer.2017.050119

Picakciefe, M., Acar, G., Colak, Z., \& Kilic, I. (2015). The Relationship between Socio-demographic Characteristics, and Level of "Mobbing" of Health Workers in Primary Health Care. Journal of Interpersonal Violence, 1(26), http://dx.doi.org/10.1177/0886260515586360

Qureshi, M. I., Rasli, A. M., \& Zaman, K. (2014). A new trilogy to understand the relationship among organizational climate, workplace bullying and employee health. Arab Economic and Business Journal, 9(2), 133-146, https://doi.org/10.1016/j.aebj.2014.05.009

Shallcross, L., Sheehan, M., \& Ramsay, S. (2008). Workplace mobbing: Experiences in the public sector. Workplace Mobbing: Experiences in the Public Sector, 13(2), 56-70.

Shelton, T. L. (2011). Mobbing, Bullying, \& Harassment: A Silent Dilemma in the Workplace. Research Papers. Paper 149. http://opensiuc.lib.siu.edu/gs_rp/149

Staub, E., \& Pearlman, L. A. (2009). Reducing intergroup prejudice and conflict: A commentary. Journal of Personality and Social Psychology, 96, 588-594, https:// doi.org/10.1037/a0014045

Sutton, R. I. (2010). The no asshole rule. New York: Business Plus.

Tkalec, L. (2001). Šikaniranje [Victimizing]. Teorija in praksa, 38(5), 908-926.

Tong, M., Schwendimann, R., \& Zúñiga, F. (2017). Mobbing among care workers in nursing homes: A cross-sectional secondary analysis of the Swiss Nursing Homes Human Resources Project. NS International Journal of Nursing Studies, 66, 72-81, https:// doi.org/10.1016/j.ijnurstu.2016.12.005

Turhan, M. (2014). The relationship between mobbing perception and emotional exhaustion of secondary teachers. Turkish Journal of Educational Studies, 1(3).

Vveinhardt, J., \& Sroka, W. (2017). Mobbing and harassment in the steel enterprises. Metalurgija, 56(1-2), 275-278.

WBI-USA, (2014). Workplace Bullying Survey, February 2014. Retrieved from http://www.workplacebullying. org/wbiresearch/wbi-2014-us-survey/

Yuksel, M., \& Tunçsipe, B. (2011). The relationship between mobbing and organizational commitment in workplace. International Review of Management and Marketing, 1(3), 54-64.

Zakon o delovnih razmerjih [Employment Relationship Act]. (2013). Uradni List RS Št. 21/2013.

Zakon o javnih uslužbencih [Civil Servants Act]. (2007). Uradni List RS Št. 63/2007.

Živko, T., Zver, M., \& Bobek, V. (2005). Kultura v kontekstu ekonomije: študije in raziskave [Culture in the context of economics: Studies and research]. University of Primorska, Faculty of Management.
Andrej Kovačič, Ph.D. is a Guest Researcher in the Laboratory of Research in Economics and Management at the University of Udine (Gorizia branch), Italy. $\mathrm{He}$ is an active coach and chief executive manager of VEGA (scientific publishing company) and several business companies. He also manages the academic journal IIASS. He has published several research papers in international journals especially in the field of marketing, management, media and communication techniques.

Nevenka Podgornik, Ph.D. is an Assistant Professor at the School for Advanced Social Studies where she carries out pedagogical and research work. Professionally, she is also a psychotherapist with a degree in reality psychotherapy and holds a European degree in psychotherapy. She is a researcher of issues regarding relationships, problems related to various addictions and other mental health problems, and educational approaches. She is the author and co-author of various original scientific articles and monographies.

Zorica Pristov is a specialised registered nurse, employed in a large non-profit health-care organisation for more than 30 years. Her work focus is persuing quality of service for patients through improvements in organisational working conditions. She is also a member of the National Commitee for Infection Control and Prevention NAKOBO (Ministry of Health).

Andrej Raspor has a degree in Organization and a Ph. D. in Social and Management Sciences. He is an Assistant Professor and a mentor at under- and post-graduate study levels at the School of Advanced Social Studies, Nova Gorica and DOBA Faculty of Applied Business and Social Studies Maribor. Throughout his career, he has led HRM and strategy projects. His field work includes work processes and relationships, time management, cost and service quality. He focuses on bringing theory in practice and vice versa. 